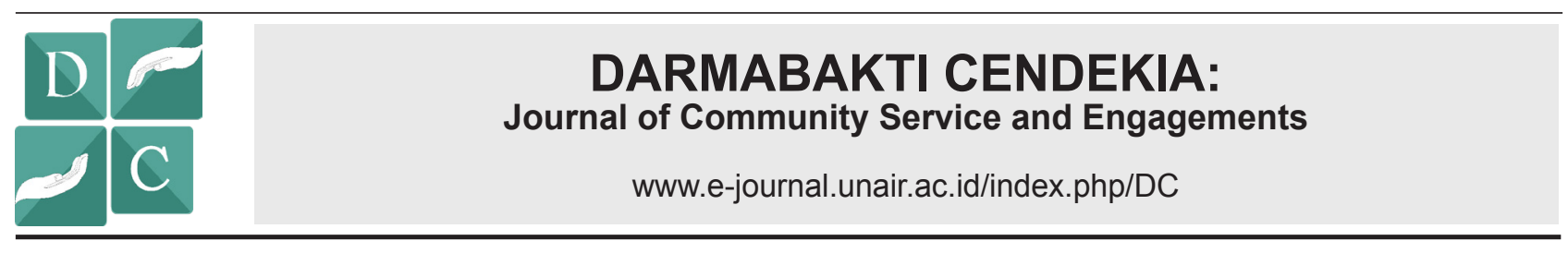

\section{STUDENT-COMMUNITY PARTNERSHIP IN IMPROVING HEALTH LITERACY TOWARD NATIONAL HEALTH INSURANCE}

\author{
KEMITRAAN MAHASISWA DAN MASYARAKAT DALAM UPAYA \\ MENINGKATAN LITERASI TERHADAP JAMINAN KESEHATAN \\ NASIONAL
}

Scope:

Social economy

\footnotetext{
Nuzulul Kusuma Putri ${ }^{1,2^{*}}$, Diansanto Prayoga² ${ }^{2}$ Syifaul Lailiyah ${ }^{2}$, Ernawaty ${ }^{1,2}$

${ }^{1}$ The Airlangga Centre for Health Policy, Universitas Airlangga, Surabaya-Indonesia

${ }^{2}$ Department of Health Policy and Administration, Faculty of Public Health, Universitas Airlangga, Surabaya-Indonesia
}

\section{A B S T R A C T}

Background: As of December 2018, BPJS Kesehatan has received application from 4,909 people to be registered as non-contribution assistance beneficiary (PBPU) through Gandrung $J K N$. Number of people to be registered to BPJS as non-contribution assistance beneficiary (PBPU) tends to fluctuate every month and tends to be stagnant in several districts, including in Licin Subdistrict. Most of people in Licin Subdistrict also not familiar with Gandrung JKN program. Objective: This student-community partnership is carried out to minimize the gap in community knowledge about what JKN is and the procedure to be registered in JKN scheme. Method: The role of students in the effort to introduce and register the community in JKN was designed by bringing the community closer to the Banyuwangi Gandrung Program. This community service consists of three stages, including activities in provisioning the students and health cadres about JKN and Gandrung JKN, direct socialization by students in the Licin subdistrict community, and efforts to provide closer access of community to BPJS Kesehatan. Results: The debriefing in the first stage was given directly by the Banyuwangi Branch BPJS Kesehatan to increase students' knowledge of JKN. Students then successfully carried out direct socialization to the Licin subdistrict community. Three villages were successfully accompanied and performed a high level of participation in the socialization session. Community service has also succeeded in bringing people closer to BPJS Kesehatan. Conclusion: The information conveyed in this activity was well received by the community because it was tailor-made according to the information needed by each family. Student assistance sharpens students' ability to communicate and understand JKN. Although the assistance succeeded in increasing the community's knowledge, in the short term it did not significantly increase the desire to register to become a JKN participant.

\section{A B S T R A K}

Latar belakang: Jumlah Peserta Bukan Penerima Upah (PBPU) BPJS cenderung fluktuatif setiap bulan dan cenderung stagnan pada beberapa kecamatan termasuk pada Kecamatan Licin. Penduduk Kecamatan Licin juga belum banyak yang menggunakan program Gandrung JKN dalam melakukan registrasi kepesertaan. Tujuan: Pendampingan berbasis kemitraan mahasiswa-masyarakat ini dilakukan untuk meminimalkan kesenjangan pengetahuan masyarakat terhadap apa itu JKN dan tata cara pendaftarannya. Metode: Peran mahasiswa dalam upaya mengenalkan dan mendaftarkan masyarakat pada JKN dirancang dengan mendekatkan masyarakat pada Program Gandrung Banyuwangi. Pengabdian masyarakat ini terdiri dari tiga tahap yakni pembekalan mahasiswa dan kader kesehatan tentang JKN dan Gandrung JKN, direct socialization oleh mahasiswa pada masyarakat Kecamatan Licin, serta upaya mendekatkan akses masyarakat Kecamatan Licin dengan BPJS Kesehatan. Hasil: Pembekalan pada tahap pertama diberikan langsung oleh BPJS Kesehatan Cabang Banyuwangi meningkatkan pengetahuan mahasiswa terhadap JKN. Mahasiswa dapat menjalankan dengan baik direct socialization pada masyarakat Kecamatan Licin. Tiga desa berhasil didampingi dengan tingkat kepesertaan yang tinggi pada sesi sosialisasi. Pengabdian masyarakat juga berhasil mendekatkan akses masyarakat terhadap BPJS Kesehatan. Kesimpulan: Informasi yang disampaikan dalam kegiatan ini dapat diterima dengan baik oleh masyarakat karena bersifat tailor-made sesuai dengan informasi yang dibutuhkan oleh masing-masing keluarga. Pendampingan mahasiswa mengasah kemampuan mahasiswa dalam berkomunikasi dan memahami tentang JKN. Walaupun pendampingan berhasil meningkatkan pengetahuan masyarakat, namun dalam jangka waktu singkat tidak signifikan meningkatkan keinginan untuk mendaftar menjadi peserta JKN.

\section{A R T I CLE INFO}

Recieved 20 Februari 2020 Accepted 18 September 2020 Online 6 Desember 2020

*Correspondence (Korespondensi): Nuzulul Kusuma Putri

E-mail:

nuzululkusuma@fkm.unair.ac.id

Keywords:

Partnership; Student; Literacy; National Health Insurance

Kata kunci:

Kemitraan; Mahasiswa; Literasi; JKN 


\section{PENDAHULUAN}

Badan Penyelenggara Jaminan Sosial (BPJS) Kesehatan mulai beroperasi sejak 1 Januari 2014 dan menandai berlakunya Jaminan Kesehatan Nasional (JKN). JKN membawa perubahan massif dalam pengelolaan pelayanan kesehatan di Indonesia. Pemerintah menargetkan bahwa melalui JKN, Indonesia akan mencapai Universal Health Coverage pada akhir 2019. Hingga Februari 2019, BPJS Kesehatan telah mengklaim bahwa 217.549.455 penduduk Indonesia telah terdaftar dalam JKN. Namun sebagai kabupaten dengan luas wilayah terluas di Pulau Jawa, Kabupaten Banyuwangi baru berhasil mendaftarkan 52,01\% penduduknya pada JKN (Agustin, 2018).

Sebagai upaya meningkatkan kepesertaan masyarakat Banyuwangi dalam JKN, Pemerintah Kabupaten Banyuwangi bekerjasama dengan BPJS Kesehatan Cabang Banyuwangi merilis program Gerakan Desa Urun Bareng JKN (Gandrung JKN) pada September 2017. Program ini memberikan masyarakat memudahkan pelayanan pendaftaran masyarakat sekaligus memberikan kesempatan bagi perangkat desa meningkatkan cakupan kepesertaan di desanya. Selain sebagai upaya untuk meningkatkan kepesertaan, program Gandrung JKN juga bertujuan untuk mengurangi antrian di Kantor Cabang BPJS Kesehatan. Gandrung JKN pada Smart Kampung (desa dengan konektivitas internet) memberikan kemudahan bagi masyarakat di Kabupaten Banyuwangi untuk melakukan pendaftaran di Kantor Desa atau Kecamatan sehingga tidak perlu datang ke Kantor BPJS Kesehatan.

Hingga Desember 2018, BPJS Kesehatan telah menerima registrasi peserta Peserta Bukan Penerima Upah (PBPU) sejumlah 4.909 jiwa melalui Gandrung JKN (Agustin, 2018). Namun sayangnya jumlah ini fluktuatif setiap bulannya dan cenderung stagnan pada beberapa kecamatan termasuk pada Kecamatan Licin. Kecamatan Licin dihuni oleh 29.347 penduduk yang tinggal di 8 desa (Badan Pusat Statistik, 2016). Walaupun kecamatan ini tidak berada di daerah perifer Kabupaten Banyuwangi, BPJS Kesehatan Cabang Banyuwangi memprioritaskan peningkatan kepesertaannya. Penduduk Kecamatan Licin juga belum banyak yang menggunakan program Gandrung JKN dalam melakukan registrasi kepesertaan.

Pada pengabdian masyarakat yang telah dilakukan oleh tim pada tahun 2014, tim menemukan bahwa mayoritas mahasiswa masih memiliki pengetahuan yang rendah tentang JKN(Putri and Ernawaty, 2018). Sebagai calon Sarjana Kesehatan Masyarakat, mahasiswa perlu memahami bagaimana sistem JKN dan apa kendala yang dihadapi oleh BPJS Kesehatan dalam mengelola sistem ini. Kecamatan Licin merupakan daerah binaan dari PSDKU Banyuwangi. Maka sudah seharusnya peran mahasiswa dapat dioptimalkan dalam membantu tercapainya tujuan JKN.

Berdasarkan analisis situasi tersebut maka pengabdian masyarakat ini disusun untuk mewujudkan kemitraan mahasiswa dan masyarakat dalam upaya meningkatan literasi terhadap Jaminan Kesehatan Nasional.

\section{METODE}

Kegiatan ini dirancang berdasarkan pola kemitraan produktif. Mahasiswa dan masyarakat diposisikan memiliki common interest terhadap JKN. Mahasiswa membantu masyarakat untuk dapat mendaftarkan dirinya pada JKN melalui Gandrung JKN. Dengan berinteraksi dengan masyarakat dan BPJS Kesehatan, pengetahuan mahasiswa terhadap JKN diharapkan akan lebih baik. Untuk dapat melaksanakan kemitraan tersebut maka pengabdian masyarakat ini disusun dalam beberapa tiga tahapan.

\section{Pembekalan mahasiswa dan kader kesehatan tentang JKN dan Gandrung JKN (5 September 2019)}

Sebelum mahasiswa diterjunkan ke masyarakat untuk memberikan pendampingan, mahasiswa diberikan pembekalan tentang apa itu JKN dan bagaimana cara kerja Gandrung JKN. Pembekalan ini diberikan langsung oleh BPJS Kesehatan Cabang Banyuwangi pada 5 September 2019. Pembekalan ini dilakukan pada 37 peserta mahasiswa S1 Kesehatan Masyarakat PSDKU Banyuwangi. Dengan mengikuti pembekalan ini, masalah rendahnya pengetahuan mahasiswa terhadap JKN dapat diselesaikan. Desain ini juga membantu tim dalam melihat model intervensi mana, yang diberikan oleh orang di luar masyarakat (mahasiswa) atau pihak masyarakat, yang lebih efektif menggerakan masyarakat mendaftar JKN. Target pada tahap ini adalah peningkatan pengetahuan mahasiswa dan juga refreshing pengetahuan kader.

Direct Socialization oleh mahasiswa pada
masyarakat Kecamatan Licin (29 Oktober 2019) Mahasiswa diterjunkan pada masyarakat untuk mulai memperkenalkan JKN. Peningkatan pengetahuan masyarakat tentang JKN dan Gandrung JKN. Sosialiasi langsung kepada masyarakat diberikan oleh mahasiswa selama mahasiswa melakukan pendampingan di masyarakat. Kegiatan ini dilaksanakan bersama dengan kegiatan BPJS Kesehatan cabang 
Banyuwangi. Target pada tahap ini adalah adanya peningkatan pengetahuan masyarakat tentang JKN dan Gandrung JKN. Mendekatkan akses masyarakat Kecamatan Licin
dengan BPJS Kesehatan (Oktober-November
2019)

Untuk lebih memperkuat keinginan masyarakat dalam mendaftarkan diri pada JKN, maka ada dua kegiatan yang dilakukan yakni sosialisasi oleh BPJS Kesehatan dan juga pendampingan mahasiswa. Sosialisasi dilakukan oleh BPJS Kesehatan ini ditujukan agar masyarakat lebih memahami manfaat dan kemudahan dalam menggunakan JKN. Pendampingan mahasiswa untuk membantu masyarakat mendaftarkan diri dilakukan agar mahasiswa dapat membantu masyarakat yang sudah memiliki keinginan untuk mendaftar namun mengalami kesulitan untuk melakukan pendaftaran. Mahasiswa berkelompok mengikuti kegiatan kemasyarakatan yang ada sambil menyisipkan informasi mengenai JKN. Mahasiswa juga melakukan kunjungan rumah ke rumah tangga yang belum terpapar informasi JKN yang disampaikan pada kegiatan kemasyarakatan. Target dari kegiatan ini adalah masyarakat dapat terbantu untuk mendaftarkan dirinya pada JKN.

Tim pengbadian masyarakat melibatkan BPJS Kesehatan sebagai mitra untuk memberikan dasar pengetahuan bagi masyarakat dan mahasiswa. BPJS Kesehatan juga selalu dilibatkan dalam kegiatan pendampingan sebagai pemonitor hasil kerja mahasiswa dalam melakukan pendampingan. Dengan melibatkan BPJS Kesehatan dalam kegiatan monitoring maka BPJS Kesehatan dapat mengkoreksi jika ada prosedur mahasiswa yang tidak sesuai dengan aturan kepesertaan yang ada. Dalam tahap ini, mahasiswa dan kader sebagai pendamping diberikan panduan pendampingan yang telah disusun oleh tim.

\section{HASIL DAN PEMBAHASAN}

Masalah rendahnya jumlah kepesertaan JKN untuk kelompok non PBI mandiri merupakan masalah utama dalam peningkatan kepesertaan JKN (Hana, 2019). Padahal kelompok ini merupakan kelompok peserta yang paling banyak menggunakan pelayanan kesehatan dengan JKN (Rolindrawan, 2015). Kepesertaan non-PBI sendiri di Kabupaten Banyuwangi juga masi rendah walaupun Pemerintah Kabupaten Banyuwangi dan BPJS Kesehatan telah bekerjasama mendekatkan akses masyarakat ke BPJS Kesehatan melalaui Program Gandrung Banyuwangi (Agustin, 2018). Masalah rendahnya pemanfaatan Program Gandrung JKN ini diduga karena masyarakat belum memahami kemudahan yang ditawarkan oleh Program Gandrung JKN serta rendahnya pengetahun masyarakat tentang apa itu JKN. Oleh karena itu, pengabdian masyarakat ini dirancang untuk dapat meningkatkan pengetahuan masyarakat melalui penataan peran mahasiswa dalam mendukung kebijakan JKN.

\section{Pembekalan mahasiswa dan kader kesehatan tentang JKN dan Gandrung JKN}

Sesuai dengan desain pengabdian masyarakat ini maka dilaksanakan pembekalan mahasiswa dan kader kesehatan tentang JKN dan Gandrung JKN. Pembekalan mahasiswa ini bertujuan untuk memberikan pengetahuan dan kemampuan untuk dapat mendampingi masyarakat tentang JKN dan Gandrung JKN. Kegiatan ini terlaksana berkat kerjasama BPJS Kesehatan cabang Banyuwangi dengan FKM Universitas Airlangga.

Mahasiswa juga merupakan salah satu kelompok yang harus diperhatikan kebutuhan untuk mendapatkan perlindungan asuransi kesehatan ada di era Jaminan Kesehatan Nasional. Pada pembekalan mahasiswa diketahui bahwa belum semua mahasiswa PSDKU S1 Kesehatan Masyarakat terdaftar sebagai peserta JKN. Masih ada 7 mahasiswa dari 37 mahasiswa yang bersedia menjadi pendamping dalam kegiatan ini masih belum terdaftar sebagai peserta JKN. Hal ini sesuai dengan penelitian yang dilakukan sebelumnya bahwa mahasiswa yang memiliki risiko untuk membayar secara out-of-pocket pelayanan kesehatan selama menempuh pendidikan cukup tinggi (35,5\%) (Putri and Ernawaty, 2017). Hal ini menjadi catatan bagi tim pengabdian masyarakat untuk juga memberikan edukasi bagi mahasiswa untuk dapat mendaftar JKN.

Tabel 1. Tingkat pengetahuan mahasiswa tentang JKN dan Gandrung JKN sebelum dan sesudah pembekalan

\begin{tabular}{ccccc}
\hline \multirow{2}{*}{$\begin{array}{c}\text { Tingkat } \\
\text { Pengetahuan }\end{array}$} & \multicolumn{2}{c}{$\begin{array}{c}\text { Sebelum } \\
\text { pembekalan }\end{array}$} & \multicolumn{2}{c}{$\begin{array}{c}\text { Sesudah } \\
\text { pembekalan }\end{array}$} \\
\cline { 2 - 5 } & $\mathbf{n}$ & $\%$ & $\mathbf{n}$ & $\%$ \\
\hline Sedang & 35 & 97.2 & 2 & 5.6 \\
Tinggi & 1 & 2.8 & 31 & 86.1 \\
Tidak mengisi & 0 & 0 & 3 & 8.3 \\
\hline Total & 36 & 100.0 & 36 & 100.0 \\
\hline
\end{tabular}

Tabel 1 menunjukkan bahwa pembekalan yang telah dilakukan meningkatkan pengetahuan mahasiswa tentang JKN dan Gandrung JKN. Setidaknya ada $86.1 \%$ mahasiswa yang memiliki pengetahuan baik setelah mengikuti pendampingan.

Pembekalan yang dilakukan untuk kader bersifat refreshing karena kader sebelumnya telah 
dibekali oleh BPJS Kesehatan saat perekrutan kader JKN dilakukan. Tim tidak melakukan pengukuran peningkatan pengetahuan kader pada tahap ini. Hal ini karena semua proses yang berkaitan dengan kader dilakukan oleh BPJS Kesehatan.

\section{Direct Socialization oleh mahasiswa pada masyarakat Kecamatan Licin}

Persepsi pengguna terhadap kemudahan dalam menggunakan JKN (percieved ease of use) mempengaruhi sikap individu terhadap JKN. Niat individu untuk menggunakan JKN dipengaruhi oleh persepsi kegunaan (percieved usefulness), sikap dan norma subyektif dan kontrol perilaku yang dirasakan (Ernawaty and Dimantri, 2017). Hal ini mendasari pelaksanaan sosialisasi kepada masyarakat tentang bagaimana kemudahan dalam mendaftar JKN melalui Program Gandrung JKN. Sosialiasi langsung kepada masyarakat diberikan oleh mahasiswa selama mahasiswa melakukan pendampingan di masyarakat. Kegiatan ini dilaksanakan bersama dengan kegiatan BPJS Kesehatan cabang Banyuwangi.

Tabel 2. Tingkat pengetahuan mahasiswa tentang JKN dan Gandrung JKN sebelum dan sesudah pembekalan

\begin{tabular}{ccc}
\hline Desa & $\begin{array}{c}\text { Jumlah peserta } \\
\text { yang terpapar }\end{array}$ & Jumlah pendamping \\
\hline Jelun & 33 & 7 mahasiswa \\
Segobang & 29 & $\begin{array}{c}\text { 10 mahasiswa dan 2 } \\
\text { kader JKN } \\
\text { Gumuk }\end{array}$ \\
\hline
\end{tabular}

Tabel 2 menunjukkan target hasil kegiatan direct socialization. Pada kegiatan ini, tim pengabdian masyarakat berhasil mengumpulkan beberapa pertanyaan dari masyarakat tentang BPJS Kesehatan dan JKN. Pertanyaan ini muncul pada semua desa yang didampingi. Beberapa pertanyaan yang sering disampaikan oleh peserta kegiatan dirangkum dalam Tabel 3.

Pertanyaan yang muncul dalam pelaksanaan sosialisasi ini digunakan sebagai dasar dalam mahasiswa melakukan pendampingan terhadap masyarakat. Jawaban pertanyaan ini dirumuskan oleh tim pengabdian masyarakat serta BPJS Kesehatan dan ditulis dalam buku panduan pendampingan yang akan diberikan ke setiap mahasiswa.

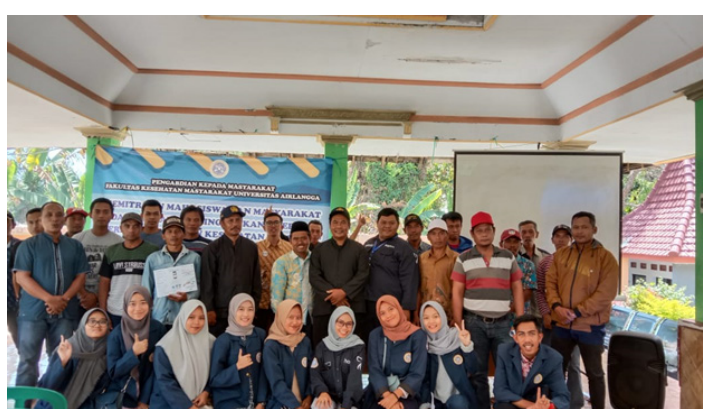

Gambar 1. Direct socialization yang dilakukan di salah satu desa

\section{Pendampingan oleh mahasiswa}

Pendampingan ini merupakan kegiatan utama yang direncanakan dalam pengabdian masyarakat ini. Pendampingan dilakukan oleh mahasiswa sesuai buku panduan yang diberikan oleh tim. Sesuai dengan buku panduan maka setiap kepala keluarga yang belum terdaftar JKN dikunjungi oleh mahasiswa minimal dua kali. Kunjungan rumah pertama yang dilakukan selama dua minggu pertama pelaksanaan pendampingan ditujukan

Tabel 3. Daftar pertanyaan yang disampaikan masyarakat tentang BPJS Kesehatan

a.Status kepesertaan anggota keluarga (yang tertera dalam kartu keluarga) yang dapat ditanggung dalam JKN baik pada peserta PBI maupun non PBI

Kepesertaan

b. Kepemilikan kartu dan status penonaktifan kepesertaan JKN KIS bagi yang menunggak iuran

c. Sanksi saat peserta menunggak iuran

\begin{tabular}{cl}
\hline Segobang & $\begin{array}{l}\text { a.Perbedaan BPJS kesehatan dan BPJS ketenagakerjaan } \\
\text { b.Penggunaan asuransi kesehatan swasta saat sudah terdaftar sebagai } \\
\text { peserta BPJS Kesehatan } \\
\text { c. Kewajiban pemberi upah dalam pelaksanaan JKN } \\
\text { d. Nasib uang iuran yang tidak pernah digunakan untuk berobat }\end{array}$ \\
\hline Gumuk & $\begin{array}{l}\text { a. Daftar fasilitas kesehatan yang bekerjasama dengan BPJS Kesehatan } \\
\text { b.Prinsip portibilitas JKN } \\
\text { C. Percievied quality pada pelayanan pasien umum dan JKN }\end{array}$ \\
\hline
\end{tabular}


agar mahasiswa melakukan identifikasi penyebab masyarakat tidak mendaftar atau menunggak iuran JKN. Penyebab yang teridentifikasi ini selanjutnya diintervensi pada kunjungan rumah kedua yang dilakukan selama dua minggu terakhir pendampingan. Pada tahap ini mahasiswa membantu masyarakat untuk mendaftar melalui Gandrung JKN. Dalam melakukan pendampingan, tim membekali mahasiswa dengan buku panduan untuk pendamping mahasiswa, desain intervensi pelaksanaan pendampingan, serta panduan kunjungan rumah.

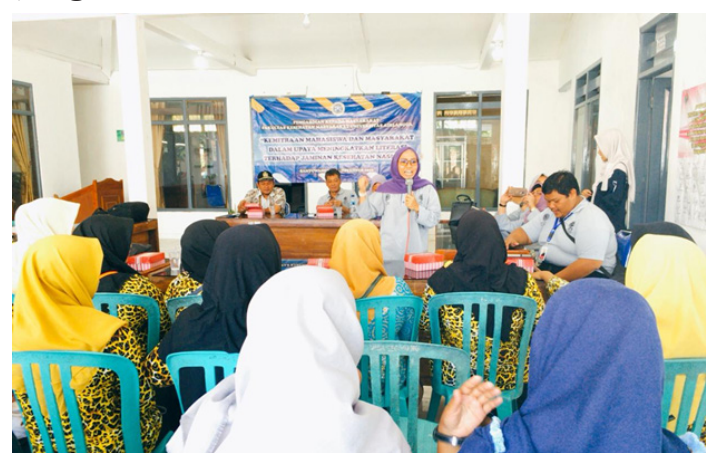

Gambar 2. Evaluasi pendampingan yang dilakukan bersama kader JKN dan Pemerintah Kecamatan Licin

Hasil evaluasi menunjukkan bahwa kemitraan mahasiswa dengan masyarakat ini efektif untuk meningkatkan pengetahuan namun kurang begitu efektif untuk memaksa masyarakat mendaftar JKN. Kesediaan masyarakat untuk mendaftar dipengaruhi oleh banyak faktor, tidak hanya semata-mata karena pengetahuan. Kemitraan mahasiswa dan masyarakat meningkatkan pengetahuan masyarakat namun tidak signifikan mendorong masyarakat mendaftar JKN. Walaupun peningkatan pengetahuan ini telah didukung oleh aktivitas yang mendorong perceived of use (pada tahap pendampingan), keinginan masyarakat untuk mendaftar JKN masih sangat rendah (Ernawaty and Dimantri, 2017). Berdasarkan evaluasi yang dilakukan dengan kader JKN tentang efektivitas pendampingan, tim menemukan bahwa masyarakat selalu menghitung untung rugi secara ekonomi. Masyarakat belum memahami arti kesehatan sebagai investasi. Selain itu, beberapa kader juga menyampaikan bahwa masyarakat menolak mendaftar JKN karena terpengaruh isu yang menyatakan pelayanan dengan JKN memiliki kualitas yang lebih rendah daripada pelayanan kelas umum (Putri and Ernawaty, 2019).

Pada level mahasiswa sendiri pun demikian. Belumsemuamahasiswayangmenjadipendamping terdaftar. Hal ini semakin menguatkan bahwa pengetahuan yang baik tentang JKN tidak dapat menjadi patokan keinginan seseorang bergabung menjadi peserta JKN (Putri and Ernawaty, 2019). Walaupun telah terpapar dengan pengetahuan terkait JKN, mahasiswa tidak serta merta mendaftar JKN. Berbeda dengan alasan yang ditemukan pada masyarakat. Alasan mahasiswa tidak mendaftar karena mahasiswa bukanlah sebagai pengambil keputusan. Keputusan mendaftar atau tidak berada di tangan orang tua mengingat pendaftaran pada JKN bersifat satu keluarga (Putri and Ernawaty, 2017).

\section{KESIMPULAN DAN SARAN}

Pengabdian masyarakat ini berhasil meningkatkan pengetahuan mahasiswa serta masyarakat tentang JKN. Kemitraan yang terjalin antara masyarakat dan mahasiswa menjadi modal sosial untuk dapat memperkuat keberhasilan cakupan semesta dalam JKN. Pembekalan untuk mahasiswa tentang JKN dan Gandrung JKN secara efektif meningkatkan pengetahuan mahasiswa tentang JKN. Informasi yang disampaikan dalam pengabdian masyarakat ini lebih dapat diterima oleh masyarakat karena lebih tailor-made sesuai dengan informasi yang dibutuhkan oleh masingmasing keluarga. Selain itu, pendampingan mahasiswa mengasah kemampuan mahasiswa dalam berkomunikasi dan memahami tentang JKN. Walaupun pendampingan berhasil meningkatkan pengetahuan masyarakat, namun dalam jangka waktu singkat tidak signifikan meningkatkan keinginan untuk mendaftar menjadi peserta JKN. Oleh karena itu, kemitraan selanjutnya harus melibatkan unsur pemerintah sehingga program yang dijalankan memiliki kekuatan formal untuk membantu masyarakat untuk mendaftar. Pemetaan awal tentang data kepesertaan dan rencana tindak lanjut perlu didiskusikan ulang dengan para perangkat desa dan BPJS Kesehatan serta melibatkan unsur pemerintah daerah.

\section{UCAPAN TERIMA KASIH}

Pengabdian masyarakat ini terselenggara oleh kerjasama Departemen Administrasi dan Kebijakan Kesehatan FKM Universitas Airlangga dengan BPJS Kesehatan cabang Banyuwangi. Kegiatan dalam pengabdian masyarakat ini dibiayai oleh Universitas Airlangga. Penulis menyatakan tidak ada konflik kepentingan dengan pihak-pihak yang terkait dalam kegiatan pengabdian kepada masyarakat ini.

\section{DAFTAR PUSTAKA}

Agustin, H. 2018. Program Gandrung JKN. Banyuwangi: BPJS Kesehatan Banyuwangi Branch. 
Badan Pusat Statistik. 2016. Kecamatan Licin dalam Angka 2018.

Ernawaty, E. and Dimantri, C. N. 2017. Why People Decide to Participate in National Health Insurance? Based on Theory of Planned Behaviour and Technology Acceptance Model. Inahea. Pp. 257-260.

Hana, O. D. 2019. Realisasi Target JKN Meleset. Bisnis Indonesia. 3 January, p. 14.

Putri, N. K. and Ernawaty, E. 2017. The Changing Nature of Campus Health Insurance: Testing Portability Issues of National Health Insurance. Inahea. Pp. 14-19.

Putri, N. K. and Ernawaty, E. 2018. The Changing Nature of Campus Health Insurance: Testing Portability Issues of National Health Insurance. Proceedings of the 4th Annual Meeting of the Indonesian Health Economics Association (INAHEA 2017). Pp. 14-19. doi: 10.5220/0007022700140019.
Putri, N. K. and Ernawaty, E. 2019. Viral Marketing Content for Universal Health Coverage Campaign in Indonesia. International Journal of Pharmaceutical and Health Marketing.

Rolindrawan, D. 2015. The Impact of BPJS Health Implementation for the Poor and Near Poor on the Use of Health Facility. Procedia Social and Behavioral Sciences. Elsevier B.V., 211(September). Pp. 550-559. doi: 10.1016/j. sbspro.2015.11.073. 